\title{
Chronic Kidney Disease: Current Situation in Togo
}

Tsevi MY1 , Nemi KD², Djagadou KA ${ }^{2}$, Amekoudi EY', Tchamdja T², Attisso E', Balaka A $^{2}$ and Ackoundou N'Guessan Kan C 3

${ }^{1}$ Department of Nephrology and Hemodialysis, University Hospital Sylvanus Olympio of Lomé, University of Lome, Togo

${ }^{2}$ Department of Internal Medicine, University Hospital Sylvanus Olympio Lomé, University of Lome, Togo

${ }^{3}$ Department of Nephrology, Hemodialysis and Renal Transplantation of Yopougon University Hospital Felix Houphouet Boigny University, Abidjan, Ivory Coast

"Corresponding author: Tsevi MY, Department of Nephrology and Dialysis, Sylvanus Olympio University Teaching Hospital, University of Lomé, BP: 61842 Lome, Togo, Tel: 22890726289; E-mail: tseviclaude@gmail.com

Received date: May 17, 2019; Accepted date: June 05, 2019; Published date: June 16, 2019

Copyright: (C) 2019 Tsevi MY, et al. This is an open-access article distributed under the terms of the Creative Commons Attribution License, which permits unrestricted use, distribution, and reproduction in any medium, provided the original author and source are credited.

\begin{abstract}
Objective: To describe the situations of discovery of CKD (CKD) in Togo.

Patients and methods: This was a cross-sectional and descriptive study conducted in the nephrology department of Sylvanus Olympio University teaching hospital (Lomé). This study was conducted from January 1st, 2017 to December 31st, 2018 for patients with CKD.

Results: The mean age was 44.08 years old with extreme ages of 18 to 71 years and a sex ratio of 1.56 . The majority of patients came from urban areas in $68 \%$ of cases. The main antecedents were dominated by traditional medication in $69.5 \%$ of cases, followed by hypertension in $66.1 \%$ of cases. One hundred patients $(84.7 \%)$ out of the 118 enrolled were referred from a health facility. Of these referred patients, $78 \%$ came from a public health center and $16 \%$ from private centers. University hospitals are at the forefront of referral centers with $30 \%$ of cases. The clinical manifestation at admission was dominated by edema (35.2\%), dyspnea (33.9\%) and hypertension (11.5\%). $93.2 \%$ of patients were in stage 5 of CKD at admission.
\end{abstract}

Conclusion: CKD is a reason for hospitalization quite frequent in our service. His prognosis is redoubtable. Emphasis must be placed on better distribution of health human resources in the diagnosis and monitoring of CKD.

Keywords: CKD; Discovery situations; Lomé-Togo

\section{Introduction}

Chronic Kidney Disease (CKD) is an insidious disease that often has few early symptoms [1]. It is very often diagnosed at the terminal stage in the 1990s in Western countries [2] but still relevant in developing countries [3]. Before the advent of contest programs against non-transmissible diseases in our developing countries, CKD is a nearlate discovery. But after the implementation of such a program since May 2012 in Togo, no study has appreciated the diagnostic situation of $\mathrm{CKD}$ and the role of the health system in the discovery of the disease.

The aim of this work is to describe the situations of discovery of chronic kidney failure in the reference service for the care of CKD in Togo and secondarily to appreciate the intervention of the actors of the health system in the discovery of CKD.

\section{Materials and Methods}

It was a transversal and descriptive study carried out in the nephrology department of Sylvanus Olympio university teaching hospital of Lomé from January 1st, 2017 to December 31st, 2018. This service is the only reference service in terms of care of CKD in Togo. Included were records of adult patients, all sexes combined with CKD and establishing their first contact with the nephrology service either in hospitalization or in consultation.
CKD is defined by the presence of a glomerular filtration rate below $60 \mathrm{ml} / \mathrm{min}$ for more than three months [4] with or without normochromic normocytic anemia, hypocalcemia and renal atrophy (kidney size less than $100 \mathrm{~mm}$ ).

The parameters studied were: socio-demographic characteristics, the health center and/or the health personnel who addressed or referred the patient; clinical signs on admission;biological parameters (creatinine measured by the colorimetric method, glomerular filtration rate is estimated by the MDRD formula [5]; calcemia; $24 \mathrm{~h}$ Proteinuria, anemia, cytobacteriological examination of the urine in search of hematuria and leukocyturia);morphological parameters, namely renal ultrasound (renal atrophy is defined by kidneys less than $100 \mathrm{~mm}$ in size and a large kidney by kidneys larger than $120 \mathrm{~mm}$ ).

Severe anemia is defined by a hemoglobin level of less than $8 \mathrm{~g} / \mathrm{dl}$. A proteinuria of $24 \mathrm{~h}$ greater than $1 \mathrm{~g} / 24 \mathrm{~h}$ is considered to be of glomerular rank and less than $1 \mathrm{~g} / 24 \mathrm{~h}$ of tubular or vascular rank. No nosological classification of initial nephropathy is made in this study.

\section{Results}

A total of 118 patients were enrolled in our study. The average age was 44.08 years \pm 12.65 with extremes of 18 to 71 years. There was a male predominance with a sex ratio of 1.56 . The majority of patients came from urban areas in $68 \%$ of cases and in $38 \%$ of cases from rural areas. Five point one percent $(5.1 \%)$ of the patients were students and $84 \%$ of the patients lived as couple. 
Citation: Tsevi MY, Nemi KD, Djagadou KA, Amekoudi EY, Tchamdja T, et al. (2019) Chronic Kidney Disease: Current Situation in Togo. J Nephrol Ther 9: 328.

Page 2 of 5

\section{Antecedents}

Taking traditional medicines was predominant in $69.5 \%$ of cases; followed by hypertension in $66.1 \%$ of cases. Its average duration of evolution was 50.48 months \pm 6.1 with extremes of 1 to 240 months. These hypertensive patients were undergoing treatment in $75 \%$ of the cases (calcium inhibitors in $28.8 \%$ of cases, conversion enzyme inhibitors in $16.8 \%$, angiotensin II receptor antagonist in $21.7 \%$ of cases, beta-blockers in $5.1 \%$ of cases and centrals in $6.8 \%$ of cases). The different patient antecedents are summarized in Tables 1 and 2.

\begin{tabular}{|l|l|}
\hline Stages & Clinical features \\
\hline Stage 1 (a) & eGFR above $90 \mathrm{ml} / \mathrm{min}$ for $1.73 \mathrm{~m}^{2}$; renal function is considered normal \\
\hline Stage 2 (a) & eGFR between 89 and $60 \mathrm{ml} / \mathrm{min}$ for $1.73 \mathrm{~m}^{2}$; this stage this stage corresponds to a slightly diminished or normal low renal function \\
\hline Stage 3 & eGFR between 59 and $30 \mathrm{ml} / \mathrm{min}$ for $1.73 \mathrm{~m}^{2}$ \\
\hline Stage 4 & eGFR between 29 and $15 \mathrm{ml} / \mathrm{min}$ for $1.73 \mathrm{~m}^{2}$ \\
\hline Stage 5 & eGFR less than $15 \mathrm{ml} / \mathrm{min}$ for $1.73 \mathrm{~m}^{2}$; this is the "terminal" stage, involving the use of substitution treatment for renal failure \\
\hline $\begin{array}{l}\text { eGFR: Estimated Glomerular Filtration Rate. (a) For stages } 1 \text { and 2, we talk about kidney disease without kidney failure when other markers of renal impairment are } \\
\text { present (proteinuria, urinary sediment abnormalities, morphological or histological changes of the kidneys). }\end{array}$ \\
\hline
\end{tabular}

Table 1: Classification of CKD [4].

\begin{tabular}{|l|l|}
\hline Antecedants & Numbers (\%) \\
\hline Hypertension & $78(66.1)$ \\
\hline Diabetes & $12(10.2)$ \\
\hline Glomerulopathy & $2(1.7 \%)$ \\
\hline HIV & $24(20.3)$ \\
\hline Gravidique Toxemia & $4(3,4)$ \\
\hline Renal Polycystic & $2(1.7 \%)$ \\
\hline Tobacco & $6(5.1 \%)$ \\
\hline Traditional medicines & $82(69.5)$ \\
\hline Cardiopathy & $2(1.7 \%)$ \\
\hline
\end{tabular}

Table 2: Antecedents.

\section{Circumstances of discovery of CKD}

Mode of admission: One hundred patients (84.7\%) out of the 118 enrolled were referred or sent from a health facility and 18 patients (15.3\%) were self-consulted in the nephrology department. Of these referred patients, $78 \%$ came from a public health center and $16 \%$ from private centers. University hospitals are at the forefront of reference centers with $30 \%$ of cases, as shown in Table 3 . The health staff at the origin of the discovery was a doctor in $66.1 \%$ of cases as shown in Table 4.

\begin{tabular}{|l|l|l|}
\hline Reference Center & Frequency $(\mathbf{n})$ & Percentage (\%) \\
\hline CHU & 30 & $30.00 \%$ \\
\hline CHR & 10 & $10.00 \%$ \\
\hline Peripheral center & 28 & $28.00 \%$ \\
\hline Private health structure & 16 & $16 \%$ \\
\hline CMS downtown & 8 & $8.00 \%$ \\
\hline Not informed & 8 & $8.00 \%$ \\
\hline
\end{tabular}


Citation: Tsevi MY, Nemi KD, Djagadou KA, Amekoudi EY, Tchamdja T, et al. (2019) Chronic Kidney Disease: Current Situation in Togo. J Nephrol Ther 9: 328.

Page 3 of 5

\begin{tabular}{|c|c|c|}
\hline Total & 100 & $100.00 \%$ \\
\hline \multicolumn{3}{|c|}{ CHU: University Hospital Center; CHR: Regional Hospital Center; CMS: Community Health Center } \\
\hline \multicolumn{3}{|c|}{ Table 3: CKD Patient Reference Center. } \\
\hline Type of health staff & Frequency & Percentage \\
\hline Doctor & 78 & $66.10 \%$ \\
\hline Nurse & 12 & $10.20 \%$ \\
\hline Medical Assistant & 10 & $8.50 \%$ \\
\hline Not informed & 18 & $15.30 \%$ \\
\hline Total & 118 & $100.00 \%$ \\
\hline
\end{tabular}

Table 4: Type of referring healthcare staff.

Clinical signs at admission: Renal edema was present in $35.2 \%$ of cases; dyspnea in $33.9 \%$ of cases and Hypertension in $11.5 \%$ of cases. Clinical signs at admission are summarized in Table 5.

\begin{tabular}{|c|c|}
\hline Clinical signs & Numbers (\%) \\
\hline Renal edema & $42(35.2)$ \\
\hline Dyspnea & $40(33.9)$ \\
\hline Digestive disorders & $26(22.0)$ \\
\hline Disorders of consciousness & $8(6.8)$ \\
\hline Acute hypertensive crisis & $14(11.5)$ \\
\hline Infection (pulmonary, urinary, sepsis) & $8(6.8)$ \\
\hline Alteration of the general condition & $2(1.6)$ \\
\hline Oliguria & $18(153)$ \\
\hline
\end{tabular}

Table 5: Distribution of patients according to clinical signs at admission.

\section{Paraclinical characteristics}

Proteinuria was present in $93.2 \%$ of patients. The average was $1754.6 \mathrm{mg} / 24 \mathrm{~h}$ with extremes of 104 to $7234 \mathrm{mg} / 24 \mathrm{~h}$. Microscopic hematuria was present in 4 patients. The mean creatinine was 1195.16 micromol/l \pm 672.7 extreme from 203.3 to $4101.76 \mathrm{micromol} / \mathrm{l}$. Table 6 shows the distribution of patients by stage of CKD, $96.4 \%$ of patients had anemia at admission. Average hemoglobin level was $7.59 \mathrm{~g} / \mathrm{dl} \pm 2.3$ with extremes of 2.8 to $14 \mathrm{~g} / \mathrm{dl}$. $74,57 \%$ of patients had severe anemia. Hypocalcemia was found in $91.52 \%$ of patients. Mean calcium level was $79.06 \mathrm{mg} / \mathrm{l} \pm 15.1$ with extremes of 53 to $154 \mathrm{mg} / \mathrm{l}$. Renal atrophy was present in $70.5 \%$ of cases as shown in Table 7 .

\begin{tabular}{|l|l|}
\hline Stage & Numbers (\%) \\
\hline Stage 1 & $0(0)$ \\
\hline Stage 2 & $0(0)$ \\
\hline Stage 3 & $4(3.4)$ \\
\hline Stage 4 & $4(3.4)$ \\
\hline
\end{tabular}


Table 6: Distribution according to the stages of CKD.

\begin{tabular}{|l|l|l|}
\hline Kidney & Frequency & Percentage \\
\hline Increased size & 2 & $2.30 \%$ \\
\hline Normal size & 24 & $27.30 \%$ \\
\hline Small size & 62 & $70.50 \%$ \\
\hline Total & 88 & $100.00 \%$ \\
\hline
\end{tabular}

Table 7: Renal atrophy values.

\section{Discussion}

The average age of our population was young, as in most studies in Sub-Saharan Africa [6-9]; in contrary to Western countries where CKD affects people aged 60 and over [10]. The discovery of CKD in young patients is a particularity in Sub-Saharan Africa, probably linked to the low socio-economic level and ancestral beliefs that motivate the use of traditional medicines [11].

The male sex was predominant in this series of cases, and this is in accordance with the results of Sabi et al. [3] in 2014 and Amékoudi et al. [7] in 2016. This male predominance may be explained by the fact that the male sex is an unchangeable risk factor for CKD [4].

Most enrolled patients were referred or sent by a doctor (66.1\%). The urban health structures were the most represented in the reference centers with a predominance of university hospitals in $30 \%$ of cases. This can be explained by the fact that there is a much greater chance of discovering $\mathrm{CKD}$ in the capital or in large cities in developing countries than in rural areas [6]. This is favored by the unequal distribution of health human resources [11], in particular health personnel informed and trained on CKD (nephrologist, other specialists, generalists, nurses, dieticians, medical assistants). This situation paralyzes the early screening of CKD leading to patients generally arriving at the end stage (93.6\% of cases) in our study. This high rate found is similar to those found in African [12-14]. Despite the establishment of a kidney disease program in our country since 2012, patients are still being discovered at a very late stage. This can be explained on one hand by the inadequacies or the almost absent screening strategies for kidney disease, and on the other hand by the passivity of general doctors in the search for kidney disease in the general population and even in at-risk patients [1]. This implies the need to adapt the distribution of tasks between different health professionals, as well as a need for public actions to limit the weight of kidney disease, especially its appearance. Prevention is essential to limit the impact of a chronic disease, both at the individual and societal level [15].

Screening for CKD is the first step in the effective care of these patients. This screening must be early in patients in contact with the health system. It must be accompanied by rigorous monitoring to slow the progression of the disease to the terminal stage $[4,16]$.

The success of this follow-up is not only the responsibility of the nephrologist even though he is at the center of this care; but it is also based on a well-organized health system with a network of health care personnel made available to the patient from screening to the advent of extra-renal replacement [17]. These strategies for secondary prevention have significantly modified the epidemiology of CKD, whose screening is earlier in Western countries [15].

Clinical manifestations are polymorphic, nonspecific for kidney disease, as in most studies [6,18,19]. These are the various manifestations that lead patients to consult and again with a delay because the persistence of the signs leads to mystical explanations within the African community, probably due to lack of information of the nursing staff or the patient [6]. On the other hand, these polymorphic clinical manifestations are rare in the West because of the early care given to patients in a dialysis-transplantation program [6]. This also shows the need for information of the population, but also of the health care staff on screening for CKD regardless of the stage to reduce the time of urgent dialysis with a prognosis from the start dark.

Patients had a history of taking traditional medications in $69.5 \%$ of cases, hypertension in $66.1 \%$ cases, HIV in $20.3 \%$ of the cases and diabetes in $10.2 \%$. Ouattara et al. [6] found similar results with the presence of self-medication (38.5\%), high blood pressure (36.2\%), HIV infection (24.2\%) and diabetes mellitus (12.3\%). These antecedents are known to be important factors in the occurrence or worsening of CKD.

Almost all patients had anemia (93.2\%. They also had a hypocalcemia $(91.52 \%)$, a significant reduction in the size of their kidneys and an abundant proteinuria. This reflects the delay of diagnosis and care in our environments $[11,15,16]$.

\section{Conclusion}

$\mathrm{CKD}$ is belatedly diagnosed in our context with many comorbidities. The patients are put in contact with the nephrologist at the time of the extrarenal treatment with a reserved prognosis.

\section{References}

1. Krzesinski JM, Dubois B, Rorive G (2003) Prévention de l'insuffisance rénale chronique chez l'adulte. Rev Med Liege 58: 369-377.

2. Jungers P, Skhiri H, Zingraff J, Muller S, Fumeron C, et al. (1997) Bénéfices de la prise en charge précoce dans l'insuffisance rénale chronique. Presse Med 26: 1325-1329.

3. Sabi KA, Noto-Kadou-Kaza B, Amekoudi YE, Tsevi MC, Kossidze K, et al. (2014) Profil épidémioclinique des patients en primoconsultation néphrologique au Togo. Médecine et Santé Tropicales 24: 169-171. 
Citation: Tsevi MY, Nemi KD, Djagadou KA, Amekoudi EY, Tchamdja T, et al. (2019) Chronic Kidney Disease: Current Situation in Togo. J Nephrol Ther 9: 328.

Page 5 of 5

4. Krummel T, Bazin D, Faller AL, Hannedouche T (2006) Diagnostic, facteurs de risque et traitement de l'insuffisance rénale chronique de l'adulte. EMC-Néphrologie 1: 1-15.

5. National Kidney Foundation (2002) K/DOQI Clinical Practice Guidelines for CKD: Evaluation, Classification, and Stratification. Am J Kidney Dis 39: S1-266.

6. Ouattara B, Kra O, Yao H, Kadjo K, Niamkey EK (2011) Particularités de l'insuffisance rénale chronique chez des patients adultes noirs hospitalisés dans le service de médecine interne du CHU de Treichville. Néphrologie \& Thérapeutique 7: 531-534.

7. Amekoudi EY, Sabi KA, Noto-Kadou-Kaza B, Combe C (2016) Épidémiologie de la maladie rénale chronique en consultation de néphrologie au CHU Sylvanus-Olympio du Togo. Néphrologie \& Thérapeutique 12: 400.

8. Diouf B, Niang A, Ka EH, Badjane M, Moreira DT (2003) Chronical renal failure in one Dakar Hospital Department. Dakar Med 48: 185-188.

9. Diallo AD, Niamkey E, Beda Y (1997) L'insuffisance rénale chronique en Côte d'Ivoire: étude de 800 cas hospitaliers. Bull Soc Pathologie Exotique 90: 346-348.

10. Rein-Rapport annuel 2016.

11. OMS (2004) Profil de système de santé au Togo.

12. Ouattara B, Kra O, Yao H, Kadjo K, Niamkey EK (2011) Particularités de l'insuffisance rénale chronique chez des patients adultes noirs hospitalisés dans le service de médecine interne du CHU de Treichville. Néphrologie \& Thérapeutique 7: 531-534.

13. Naicker S (2010) Challenges for nephrology practice in sub-saharan Africa. Nephrol Dial Transplant 25: 649-650.

14. Sumaili EK, Krzesinski JM, Cohen EP, Nseka NM (2010) Épidémiologie de la maladie rénale chronique en République démocratique du Congo: Une revue synthétique des études de Kinshasa, la capitale. Néphrologie \& Thérapeutique 6: 232-239.

15. Duranton F, Brunet P, Laville M, Landais P, Daurès JP, et al. (2014) Prévention de la maladie rénale chronique en France : Intérêt, faisabilité et difficultés. Néphrologie \& Thérapeutique 10: 492-499.

16. Jungers P, Man NK, Joly D, Legendre C (2011) L'insuffisance rénale chroniqueख Prévention et traitement. Lavoisier 337p.

17. Laville M, Juillard L, Deléaval P, Favé S, Charlois AL, et al. (2007) Rôle des réseaux de santé dans le dépistage et la prise en charge de la maladie rénale chronique. La Presse Médicale 36: 1865-1874.

18. Bah AO, Kaba ML, Diallo MB, Kake A, Balde MC, et al. (2006) Morbidite ' et mortalite' hospitalieres dans le service de ne'phrologie de l'hopital national Donka. Mali Med 4: 66-70.

19. Sakande J, Sawadogo M, Nacoulma EWC, Sidikath ES, Kabre E, et al. (2006) Profil biologique de l'insuffisance re'nale chronique. Ann Biol Clin Que 43: 3-8. 